\title{
The Effects of Environmental Taxes on the Development of Recycling Technologies
}

\author{
Hüseyin Çakmak \\ Maltepe Üniversity, Istanbul, Turkey
}

\begin{abstract}
The industrial revolution, which is considered to be one of the most important periods of development in human history, can also be regarded as a technological revolution, but the industrial revolution has brought with an excessive production and consumption concept without any restriction until the 2000s. The countries, which started with the industrial revolution and tried to maintain the production and consumption carried out with an almost limitless resource consumption, saw that this situation was unsustainable in the 1980s and started to seek remedies. One of the most important of these remedies is the development of technologies that provide recycling of wastes resulting from current consumption. The other is the development of technologies that convert non-renewable natural resources from renewable natural resources. In addition, renewable natural resources can be achieved by creating a new technology that will enable the maximum utilization of the resources available until the time of self-renewal. In contrast to T. Malthus's population growth theory, classical economists, human beings have been able to overcome the needs of the growing population due to information and technological development. In the following process, economic growth and social prosperity can be envisaged by developing technologies that enable recycling of wastes resulting from consumption of scarce natural resources.
\end{abstract}

Keywords: environmental tax, recycling, technology

\section{Introduction}

The use of non-renewable resources, such as bags, paper, pet bottles, iron, rubble, clothes, glass, stones, etc. that are used for the use of people as goods and services and which become obsolete, worn out, and become unusable once they are used, can be made before they are used. It refers to a situation. Recycling of these substances can be attributed to technological developments in recycling. In this context, technologies that maximize consumption of resources should not be developed. Instead, technologies need to be developed to produce more than just the prosperity of the goods and services produced by using fewer natural resources. However, policies can be developed to develop technologies that allow for the transformation of the products made. The financing needs of all phases of these technologies from the R\&D process to the operational phase can be met by the income from the environmental taxes without incurring additional financial burden to the state.

The aim of this study is to reveal the positive effects of environmental taxes on technological development in the sustainable use of resources without compromising their economic growth and prosperity as well as the

Hüseyin Çakmak, Dr., asst. prof., Department of Economy, Maltepe Üniversity, Istanbul,Turkey.

Correspondence concerning this article should be addressed to Hüseyin Çakmak, Hastane Mah. Küçükesat Sok No.30/2 Ilkadım, Samsun 55040, Turkey. 
societies in their period. The aim should not be used to internalize and penalize environmental taxes only to negative externalities that lead to market failure. It can be foreseen that the sustainability of resources cannot be ensured by coercive methods. To ensure that the resources are sustainable, it is possible for the economic units to develop new methods that they can apply voluntarily within the free market system except for the punishment (Çakmak, 2018).

In this study, it will be evaluated to meet the financial resources required for the development of recycling technologies from environmental taxes. The design of the study is as follows: In the first part, while environmental taxes are given under the headings of energy, resources, transportation, and waste taxes; in the following section, the recycling rates will be evaluated and recycling mathematical modeling will be made according to the data obtained from the Environmental Directorates of Esenler, Maltepe, and Üsküdar Municipality; in the next section, the use of environmental tax revenues in the financing of recycling technologies will be examined, and the final section will include assessments and recommendations.

\section{Environmental Taxes}

The financial instruments that have been scientifically proven to have a negative impact on the environment and the economic agents that cause this activity to cover the social damages they cause can be expressed as environmental taxes. In this context, environmental taxes have been recognized by international organizations, such as EU, OECD, International Energy Agency (IEA), and WB under four headings as energy, source, pollution, and transport taxes (Çakmak, 2018).

\section{Energy Tax}

The category of energy taxes includes taxes on both energy generation and energy products used for transportation. The most important energy products for transportation are gasoline and diesel. Energy products also include fuel, natural gas, and electricity. Bio-fuel taxes and other energies derived from renewable sources are covered by this tax (EU, 2013). In addition to energy taxes, northern countries, which are applying carbon emission tax, have made considerable progress in this area.

Coal reserves of fossil fuel energy products in Turkey are also understood that the above amount to meet their own needs. The share of coal in total energy consumption in Turkey has increased sharply since 1962, in $1979,12 \%$ came to the $37 \%$ (Yilmazcan, 1984). Coal consumption has continued to increase until today. It is understood that the authorities will continue to increase from their statements. Some countries have started to use plants that are very advanced and used with modern technologies to burn waste coal that does not cause acid raining. It has also been proven that many wastes can be converted to electricity and that coal can be burned without causing acid rain (Perkins, 2017).

Turkey also that is used coal as an energy source should be able to use the new technologies in this field, if possible, even be able to conduct studies for the development of this technology. In the case of continued coal use, carbon tax revenues may be used if environmental tax revenues are applicable to the development or purchase of technologies that will provide the least amount of carbon emissions.

\section{Source Tax}

This category includes taxes on the extraction or use of natural resources (e.g., water, forests, wild flora, and fauna) (EU, 2013). Resource taxes relate to water consumption, forestry, and mining. Resource taxes are aimed at reducing negative environmental impacts while ensuring a more efficient use of natural resources. In 
this context, different taxes are applied according to natural resources. Most of the OECD countries apply a hunting fee to protect nature, as well as forest and wood-related fees in the area of biodiversity. At the same time, income from such instruments is used for conservation and sustainable management of biodiversity conservation (IEEP, 2014). In this regard, some applications are available in Turkey.

Almost all OECD countries have taxes and duties on water. In addition to the implementation of drinking water supply and consumption in relation to wastewater resources, it is also applied to ensure the protection of groundwater (IEEP, 2014). It is used to provide financial support to the management of river basins in France and Spain. It is also implemented at the regional level in Germany. The Netherlands came into force in 1995. The base of the tax is arranged as the cubic amount of the water extracted under the ground. The taxpayer is the ones who remove water from the ground (Jamali, 2007). Turkey is also in the news that it began to rapid depletion of underground water resources in some areas. Environmental taxes can be utilized if these renewable natural resources are sustainable.

The reason for applying aggregate taxes in Sweden is slightly different from other countries. The most important tax in the country is on natural gravel. This is because the gravel is the bed of groundwater. Because of the natural sand and gravel scarcity in many areas of the country, the Swedish Environmental Organization calculated that in 1994, 80 municipalities would have completed the natural gravel. Therefore, it started to implement the aggregate tax in 1996 (Çakmak, 2018). Turkey also has applications for quarry mortar.

\section{Pollution Tax}

This category includes measured or estimated emissions of air, water, and soil, and taxes on solid waste and noise. Taxes on oils may require special analysis. Waste oils are not used as energy and therefore they are considered as pollution tax. In the case of rain, it is seen that the pollution of underground and above water sources (EU, 2013) is caused.

In Austria, taxes are levied on quantity and weight. In Italy, tax is applied based on the life of the wastes. In other words, in Italy, the time period for the waste of household waste at work and households is taken as the main criterion and the cost to be disposed of is the basis for taxes. In some Dutch municipalities, the rubbish tax in the Netherlands is based on the weight of the garbage; and in some cases, it is applied according to the number of garbage bags (Jamali, 2007).

One of the countries in which this system was implemented was the local administration of the Municipality of Barcelona in Spain. This local administration has been selected as a trial by the central administration and within the framework of the powers granted to the local administration; it has been obliged to use 40- and 100-liter waste packaging standardized to houses and workplaces. The tax for the 40-liter package is 0.6 Euro, and the packaging of 100-liter is 1.5 Euro. However, in order to collect the materials that can be recycled, special containers were prepared and allowed to be disposed of without tax. Since every waste packaging means to pay taxes, an increase of $70 \%$ in the amount of recycled materials has occurred in three months. Following this success, the Municipality of Barcelona decided to expand this practice (Çakmak, 2018).

The majority of the European Union countries consider the volume of waste to minimize domestic or industrial waste. This allows consumers to choose products or packages that produce less waste, and manufacturers create products that produce less waste. In case of taxation taking into consideration the volume of waste, it is known as "pay-as-you-go uygulamada system" (Jamali, 2007). 
Some OECD countries have introduced regulations, such as taxes, fees, and pictures that directly affect fishing and marine biodiversity, such as commercial fisheries management fees and nature protection fees. In some countries, revenues from these fees are used for marine protection, conservation, and sustainable fisheries management (IEEP, 2014).

\section{Transportation Tax}

Road transport is the subject of a number of different taxes in OECD countries. Existing tax applies primarily to motor vehicles. For environmental targets, there is a scope that can be modified to reflect the restructuring of existing taxes, rather than the implementation of completely new ones (OECD, 1996). Motor minerals in Turkey are considered indirect taxes applied in environmental taxes (Cakmak, 2018).

In OECD countries, motor vehicles are usually taxed according to physical or fuel use characteristics and/or their use. These taxes vary widely among OECD countries in terms of implementation and purpose. The majority of the environmental objectives are implemented in order to generate revenue for the public. However, excise taxes on motor vehicle taxes, in particular, transportation costs, have the potential to change behavior for environmental purposes. Taxes on motor vehicles consist of sales tax on new motor vehicles, taxes or fees collected on an annual basis, and taxes on operating expenses of cars (OECD, 1996).

This category mainly includes vehicle owners' vehicle purchases and taxes on the use of motor vehicles. These taxes apply to other means of transport (aircraft, ship, or rail inventories) and related transport services (taxes on charter or scheduled flights) as well as transportation tax (Schlegelmilch \& Joas, 2015).

This includes taxes on transport vehicles that are relatively more environmentally friendly, such as rail, rail vehicles, and public transport. All taxes on transportation vehicles, taxes on electric cars, and car insurance taxes (specific taxes on vehicle insurance, excluding general insurance taxes on all types of insurance contracts) must be included (EU, 2013).

Since environmental taxes are one of the basic environmental policy instruments. It can be stated that it has a special importance in the maintenance of renewable and non-renewable natural resources by using it as an incentive factor in the development of recycling technologies in the prevention of environmental problems.

\section{Recycling}

The recycling of wastes that can be recycled by various physical and/or chemical processes into secondary raw materials and their inclusion in the production process is called recycling. It can be said that recycling means a very important situation for humanity in the processing and transformation of the second of renewable natural resources and non-renewable natural resources.

For a livable world, technological development and protection of the environment must be in harmony. Thus, the collection of which is assessed in the solid waste, separated according to types of physical, chemical, and biological raw materials is reconverted to a number of methods is important for both Turkey other countries. In this way, energy conservation is ensured while preserving natural resources. In addition to this, while reducing the amount of solid waste provides the convenience of solid waste operations, we can also express the activities that provide investment to the future and economy in the benefits of recycling.

According to Article 15 of Law No.5393-legislation on the collection of waste in Turkey, all services related to the collection, recovery, elimination, and storage of solid wastes are defined among the duties of the municipalities. Municipalities have the provision of this service by the Council of State and the decision of the 
Ministry of the Interior, which can be transferred by concession over the period of not exceeding 49 years. According to the State Tender Law No. 2886, waste collection activities can be tendered and contracts can be concluded. According to the Public Procurement Law No. 4734, municipalities can buy these services by allocating a share of their budgets.

Recycling activities play an important role in ensuring that natural resources are sustainable. Some county municipalities located in Turkey, especially Istanbul, are making significant efforts in this regard. In this study, the activities of Esenler, Üsküdar and Maltepe Municipality Environmental Protection Directorates will be evaluated both quantitatively and qualitatively.

\section{Esenler Municipality Environmental Protection Directorate’s Work}

Esenler Municipality Recycling Facilities Daily solid waste data are given in Table 1.

Table 1

Recycled Wastes

\begin{tabular}{llll}
\hline Paper cardboard & Pete-pp-pe & Steel tin & Glass \\
\hline 17 tons/day & 7 tons/day & 3 tons/day & 3 tons/day \\
\hline
\end{tabular}

The importance of recycling ensures the conservation and sustainability of natural resources. Natural resources are decreasing day by day due to the increase in world population and consumption habits. For this reason, it can contribute to the consumption of natural resources in accordance with the sustainable growth model by reducing the consumption of materials and recycling the qualified wastes.

Recycling provides energy savings by reducing the number of industrial processes in the production of materials. In the process of recycling of metal beverage cans, when these metals are directly melted and converted into a new product, the ore used for the production of these metals can be produced without the need for purification of these ores. This can save up to $96 \%$ of energy from recycling an aluminum can.

With the application of recycling, a reduction in the amount of waste going to the trash is achieved and a smaller amount of space and less energy is used for the transportation and storage of these wastes.

Recycling means investing in the future and the economy. Recycling is a productive economic investment in the long term. Economic problems will emerge as a result of the reduction of raw materials and rapid depletion of natural resources. At this point, recycling has a positive impact on the sustainability of economic growth and social welfare while contributing to the sustainability of natural resources.

The solid wastes collected for recycling at the municipality's facilities consist of iron, steel, copper, aluminum, lead, batteries, paper, plastic, rubber, glass, engine oil, waste oils, accumulator, vehicle tires, X-ray films, and electronic waste.

The municipality has 750 tons of mixed solid waste per month. Fifty percent of these are paper, $30 \%$ plastic, $10 \%$ glass, and $10 \%$ metal. It was stated that $100 \%$ of the paper and glass were transformed and that 17 adult trees were prevented when a ton of waste paper was converted due to these data. Thus, the recycling activity carried out by the Municipality of Esenler in Turkey stated that every month blocked the cutting of the 6,375 adult trees.

Glass recycling. It can be recycled $100 \%$ without losing anything from glass quality. The energy required to melt the recycled glass is less than melting the raw material needed to make a new glass bottle. Energy from a bottle recycling is enough to operate a television for an hour and a half. The largest glass furnaces 
produce more than 400 tons of glass per day. This figure is expressed in more than one million bottles and jars per day.

Recycling paper. According to the information given by the Esenler Municipality regarding the recycling processes, in case of no waste paper; 175 hectares per day in Turkey and in the world from destruction 110,000 hectares of forest every minute. The damage to the nature and the damage to the ecological balance are too heavy to be paid at any economic cost. While $60 \mathrm{~kg}$ of paper is obtained from a 20 -year-old tree, it is possible to add approximately 100-140 kg of paper/cardboard from $150 \mathrm{~kg}$ of waste paper. When 1 ton of used paper is recycled,

The carbon dioxide, which is the greenhouse gas, can be disposed of $12,400 \mathrm{~m}^{3}$.

The $12,400 \mathrm{~m}^{3}$ oxygen gas will be produced.

Protection of 17 adult trees can provide oxygen for 34 people.

The $32 \mathrm{~m}^{3}$ water consumption can be consumed by three families per month.

It saves 1,750 liters of fuel oil to be consumed by the two families for the purpose of heating in the winter months;

It is stated that it is possible to save $4,100 \mathrm{~kW} / \mathrm{h}$ electrical energy that 20 families will consume for a month.

Metal recycling. Physical grinding is carried out. After grinding, it is melted in high-grade furnaces. The melt is poured into the mold and metal blocks are formed. These metal blocks are pressed to the desired thickness. It is ready for filling after filling according to all kinds of packaging, such as aerosol, beverage can, paint can and it can be converted into raw material to be made again.

When 10 aluminum beverage cans are recycled, a $100 \mathrm{~kW} / \mathrm{h}$ lamp is saved in 35 hours, or a TV in 30 hours.

Plastic recycling. If a 2.5-liter plastic bottle is recycled and used in production, the 6-hour 60-watt electrical energy can be saved, while the plastics are crude oil derivatives, thus reducing the fossil fuel oil consumption. It also contributes to the reduction of problems, such as air pollution, global warming, and climate change.

\section{Recycling Work of Üsküdar Municipality}

The amount of waste that Üsküdar Municipality collects daily for recycling is given in Table 2.

Table 2

The Increase in Daily Waste Collection Amount of Üsküdar Municipality is Significant. The Increase in the Amount of Waste Collection Contributes to the Sustainability of Natural Resources

\begin{tabular}{llllll}
\hline Waste & $\begin{array}{l}\text { Packing } \\
\mathrm{kg} / \text { day }\end{array}$ & $\begin{array}{l}\text { Glass } \\
\mathrm{kg} / \text { day }\end{array}$ & $\begin{array}{l}\text { Vegetable oil } \\
\mathrm{kg} / \text { day }\end{array}$ & $\begin{array}{l}\text { Electronic waste } \\
\mathrm{kg} / \text { day }\end{array}$ & $\begin{array}{l}\text { Waste battery } \\
\mathrm{kg} / \text { day }\end{array}$ \\
\hline 2013 & 10.582 & 3.754 & 547 & 10 & 5.6 \\
2014 & 11.090 & 4.554 & 673 & 3.4 & 4.1 \\
2015 & 17.450 & 4.601 & 776 & 23.5 & 3.4 \\
2016 & 34.888 & 5.742 & 820 & 27.6 & 16.2 \\
\hline
\end{tabular}

Üsküdar Municipality’s bilateral collection system project. Municipal waste collection activities by taking into account certain principles within the framework of a certain plan and program increase daily amount of waste collected daily. 
The municipality has changed the procurement procedure for the solid waste service, the tender method, which is the lump sum method, as the car rental and personnel service purchase. In the period between the garbage collection and the transfer facility, the whole organization has been carried out by the municipality. In addition, the entire management of the other recyclable wastes in accordance with the project was also collected in the municipality.

While collecting and informing about the wastes separately at the source, the collection system was started on 01.03.2016. This system is referred to as the parsing model in the source.

According to the decomposition model at its source, Üsküdar is divided into two regions as the first region and the second region. Information and announcements were made in the first region on Tuesday and in the other region on Friday. It is ensured that the packaging wastes that the citizens have accumulated for a week are left in the containers on the day of collection. Accordingly, packaging wastes were started to be collected in Region 1 on Tuesday and in Region 2 on Friday, only once a week. No bags were dispensed, no extra recycling containers were placed, and no labor or energy was consumed. Citizens were asked to remove waste from recyclable paper, cardboard and plastic after 18.30 so that they would not remove garbage on the specified days. As a result of 45 days of work, the amount of recyclable wastes increased by $110 \%$.

Parsing model at the source, as labor costs in the economic conditions in Turkey, it did not bring any additional costs, such as the cost of bags. It has contributed to the fact that resources are sustainable. The first contributed through the collection of convertible solid waste. Secondly, no additional pouches were used during the implementation process.

\section{Maltepe Municipality Recycling Work}

The data related to the collection of recyclable wastes of Maltepe Municipality are given in Table 3.

Table 3

Daily Amount of Waste Collected by Maltepe Municipality

\begin{tabular}{llllll}
\hline Waste & $\begin{array}{l}\text { Packing } \\
\mathrm{kg} / \text { day }\end{array}$ & $\begin{array}{l}\text { Vegetable oil } \\
\mathrm{kg} / \text { day }\end{array}$ & $\begin{array}{l}\text { Electronic waste } \\
\mathrm{kg} / \text { day }\end{array}$ & $\begin{array}{l}\text { Waste battery } \\
\mathrm{kg} / \text { day }\end{array}$ & $\begin{array}{l}\text { Construction and excavation waste } \\
\mathrm{kg} / \text { day }\end{array}$ \\
\hline 2014 & 12.858 & 323.2 & 30 & 4.4 & - \\
2015 & 12.466 & 372.6 & 33.2 & 5.4 & - \\
2016 & 15.677 & 487.6 & 49.6 & 7.7 & 3,565 \\
\hline
\end{tabular}

Packaging waste management. Within the scope of the packaging waste management plan, it is collected from households, workplaces, hospitals, and schools as different from domestic and industrial wastes and sent to recycling.

The packaging waste management study was carried out in accordance with the Environmental Law No.2872 at Regulation on Control of Packaging Wastes

Management of vegetable waste oils. Depending on the transfer of authority from the Ministry of Environment and Urbanization, it is collected from homes, schools, and workplaces and sent for recycling. Municipalities are responsible for the regular collection and use of recyclable oils in accordance with the Sorum Regulation on Control of Vegetable Waste Oils lud under the Environmental Law No. 2872.

The amount of collection varies according to the amount of vegetable oil consumption of citizens. As a result of the studies carried out within the scope of the relevant laws and regulations, a total of $178,754 \mathrm{~kg}$ of vegetable waste oil was collected in 2016 and restored to the economy.

According to the experts of Maltepe Municipality, one liter of waste oil can make one million liters of 
water unusable and 5 million liters of water can be made to become no drinking.

Waste battery management. Recycling of waste batteries is collected in order to minimize environmental damage. Management of waste batteries is carried out under the control of Istanbul Metropolitan Municipality and with the support of the authorized TAP association. The Municipality of Maltepe carries out information activities and carries out the collection and transport of waste batteries. In 2016, 2,843 kg of waste batteries were collected.

Electronic waste management. Electronic waste, such as computer, television, printer, monitor, radio, telephone, vacuum cleaner, and washing machine is collected and sent to recycling system. In 2016, 18,122 kg of electronic waste was collected with Electronic Waste Collection Piggy Bank placed within the boundaries of the district.

Recycling and recycling of these collected waste materials can reduce the need for natural resources for production. Thus, sustainability of natural resources can be supported. In this context, this study conducted in municipalities is important in two aspects. The first is to prevent environmental pollution and the second is to perform both collection and separation processes for recycling. One of the most important economic effects of these activities is the creation of new employment areas for individuals.

\section{Mathematical Modeling of Recycling}

We can explain the subject of recycling mathematically. As an example can be calculated on a net of iron ore reserves in Turkey and assume that net 100 tons. Let us assume that the total iron demand is due to the processing of 10 tons of reserve annually. Suppose this is all produced and consumed from country resources. In this case:

End of iron reserves in the country $=$ Total amount of Iron Reserve/Annual Iron Amount is calculated by the amount of the reserve. In this case, if the recycling is equal to zero, 100 tons $/ 10$ tons $=10$ years later. In the country, the iron reserve is finished.

Under the assumption that the current technologies in the country convert non-renewable resources at the level of $1 \%, 10 \% \ldots 90 \%, 100 \%$, how many years of sustainable receivable can be calculated. The non-resources can be sustainable with the formula below:

$\mathrm{Y}=\mathrm{TDR} / \mathrm{IDR}-\mathrm{DDR}$

TDR: Total Iron Reserves

IDR: Annual Iron Reserve

DDR: Transformed Iron Reserve

$\mathrm{Y}$ is shown as sufficient year

$\mathrm{Y}=100 / 10-0=10$ years later reserves are depleted

$\mathrm{Y}=100 / 10-1=11.1$ years after reserves are depleted

$\mathrm{Y}=100 / 10-2=12.5$ years later reserves are depleted

$\cdots$

$\mathrm{Y}=100 / 10-9=100$ years later reserves are depleted

$\mathrm{Y}=100 / 10-10=\infty$

The technology provides significant advantages for the non-renewable resources to be sustainable. As technology evolves and the conversion rate reaches $100 \%$, the non-renewable resource becomes renewable at this technology level and the problem of scarcity is eliminated. Thus, since sustainability of resource consumption 
can be ensured, the needs of people, both today and in the future, can be met by technological development.

\section{Environmental Taxes In Financing of Recycling Technologies}

Technology is the science and art of making and using something. Man is the only living thing that can transform the materials of the natural world into tools, machines, and systems that will help their lives (Bridgman, 2008). In addition, people have developed faster technological advancements by using machinery and systems within the organization. Technology is an extremely important resource that offers companies a competitive advantage and growth opportunity (Çetimdamar, Phaal, \& Probert, 2013).

Technology management is the management of an organization's technological capabilities in order to shape and implement strategic and functional goals. Technological capabilities consist of numerous activities to explore and use technology. These are activities, such as acquisition, identification, learning, selection, and protection (Çetimdamar et al., 2013). This situation leads to the emergence of financial problems of competitiveness and technological development.

At this point, the state supports the companies in terms of both the national economy and the national and international competitiveness of the companies. While this situation is evaluated positively for the firms, the fact that the public does not bring an additional cost to the budget in terms of fiscal discipline will express a desired situation for governments. At this point, revenues from environmental taxes can provide solutions to the problems mentioned above. With revenues from environmental taxes, it can actually support firms in the development of technologies that will ensure the sustainability of natural resources. This application will eliminate the resource shortage required by the companies for technological development and increase their competitiveness. At the same time, they may be prevented from experiencing fiscal discipline problems in their government.

Revenue from environmental taxes can be used to ensure that the technological progress is achieved optimally, thus not becoming insufficient, eliminating uncertainty in the future, and ensuring that the inventors of the innovations find sufficient resources and implement the inventions (Akkaya, 2017).

It is possible to clearly explain the new technologies that emerge as a result of internalizing the externality of environmental pollution, to encourage innovation in an open manner, and to explain the optimal public policy set including instruments shaped to enable the dissemination and adoption of technology (Akkaya, 2017). One of the most important tools in this policy basket is environmental taxes.

Environmental taxes can be used as an important financial tool in promoting environmental technologies. In this context, there will be no shortage of resources in terms of firms. It can also be one of the most important sources to be used as it will provide an advantage over the competition.

Developing technologies to ensure the sustainability of existing natural resources is an obligation for countries to ensure a climate-resistant economic transformation. For example, standards and regulations are needed to remove coal gradually in the energy system. It may be necessary to apply subsidies for investment and financing of renewable energy systems which are relatively more expensive than fossil fuels (Karakaya, 2016). In providing this support, income from environmental taxes can be effectively used.

Energy products, known as fossil fuels, can be used as a means of promoting or inciting environmental taxes to promote the development of technologies to minimize or minimize carbon emissions in coal, oil, and natural gas consumption.

Governments can contribute to a transformation in the redesigning and structuring of the economic structure with recycling technologies and in a way that makes the social welfare steady, in line with the income 
generated from environmental taxes and the situation arising due to global warming and climate change.

\section{Conclusion and Recommendations}

Governments can create a structure to use to support environmental taxes; companies develop technologies that provide sustainability for natural resources. In this context, governments;

In particular, companies develop technologies that improve the recycling of non-renewable natural resources or technologies that transform renewable resources into non-renewable resources;

Companies can realize their production components by using recyclable materials.

It can support producers and consumers who develop technologies that will generate energy from completely renewable sources with income from environmental taxes. In addition, it can implement a policy that reduces the environmental tax rates applied to companies by zero according to the criteria determined by the development of environmental technologies.

Revenue from environmental taxes can be used as an incentive to encourage firms investing in environmental technologies in market conditions.

Environmental taxes can be used to increase the costs of companies that are not environmentally friendly and to weaken their competitiveness in the market. Thus, recycling can make a significant contribution to the conservation of natural resources; recycling can improve the idea of protecting the environment from an economic point of view in addition to creating a healthy environment.

As a result, it can be envisaged that governments, firms, society, and individuals will have a consensus on the importance of using environmental taxes to ensure the sustainability of natural resources, and a significant gain in the development of recycling technologies that will ensure economic growth and social welfare.

\section{References}

Akkaya, Ş. (2017). Yerelden Küresele Çevre Vergileri İktisadi Bir Analiz. İstanbul: Filiz Kitapevi.

Bridgman, R. (2008). Teknoloji. Ankara: Popüler Bilim Kitapları.

Çakmak, H. (2018). Çevresel Vergilerin Ekonomik Etkileri: Karbon Vergisi (Yayınlanmamıı̧ Doktora Tezi, Maltepe Üniversitesi, İstanbul).

Çetimdamar, D., Phaal, R., \& Probert, D. (2013). Teknoloji Yönetimi. Ankara: Elif Yayınevi.

EU. (2013). Environmental taxes. Luxembourg: A Statical Guade, EU.

IEEP. (2014). Environmental tax reform in Europe opportunities for the future. Hollanda: IEEP.

Jamali, T. (2007). Ekolojik Vergiler. Ankara: Yaklaşım Yayıncılık.

Karakaya, E. (2016). İklim Finansmanı: İklimle Mücadelede Rolü. Paris İklim Zirvesi Anlaşması: Düşük Karbonlu ve İklime

Dirençli Bir Ekonomiye Topluma Geçiş.

OECD. (1996). Environmental taxes in OECD countries. Paris: Head of Publication Service, OECD

Perkins, J. (2017). Bir Ekonomik Tetikçinin İtirafları 1. İstanbul: April Yayıncılık.

Schlegelmilch, K., \& Joas, A. (2015). Fiscal considerations in the design of green tax reforms. Venice, Italy: Green Growth Knowledge Platform.

Yılmazcan, D. H. (1984). Air pollution and energy. Marmara Üniversitesi İktisadi ve İdari Bilimler Fakültesi Dergisi, (365), 115-126. 